\title{
Biotechnology and Plant Disease Control-Role of RNA Interference
}

\author{
Shabir H. Wani ${ }^{1 *}$, Gulzar S. Sanghera ${ }^{2}$, N. B. Singh ${ }^{3}$ \\ ${ }^{1}$ Biotechnology Laboratory, Central Institute of Temperate Horticulture, Srinagar, Jammu and Kashmir, India; ${ }^{2}$ Rice Research \& \\ Regional Station (SKUAST-K) Khudwani, Anantnag Jammu and Kashmir, India; ${ }^{3}$ Department of Plant Breeding and Genetics, COA, \\ Central Agricultural University, Imphal, Manipur, India. \\ Email: *shabirhussainwani@gmail.com
}

Received July $10^{\text {th }}, 2010$; revised August $24^{\text {th }}, 2010$; accepted September $3^{\text {rd }}, 2010$.

\begin{abstract}
Development of crop varieties which are resistant against many economically important diseases is a major challenge for plant biotechnologists worldwide. Although much progress in this area has been achieved through classical genetic approaches, this goal can be achieved in a more selective and robust manner with the success of genetic engineering techniques. In this regard, RNA interference (RNAi) has emerged as a powerful modality for battling some of the most notoriously challenging diseases caused by viruses, fungi and bacteria. RNAi is a mechanism for RNA-guided regulation of gene expression in which double-stranded ribonucleic acid (dsRNA) inhibits the expression of genes with complementary nucleotide sequences. The application of tissue-specific or inducible gene silencing in combination with the use of appropriate promoters to silence several genes simultaneously will result in protection of crops against destructive pathogens. RNAi application has resulted in successful control of many economically important diseases in plants.
\end{abstract}

Keywords: RNAi, Viruses, Fungi, dsRNA, Gene Silencing

\section{Introduction}

Plant diseases are a threat to world agriculture. Significant yield losses due to the attack of pathogen occur in most of the agricultural and horticultural crop species. More than $70 \%$ of all major crop diseases are caused by fungi [1]. Plant diseases are usually handled with applications of chemicals. For some diseases, chemical control is very effective; but it is often non-specific in its effects, killing beneficial organisms as well as pathogens. Chemical control may have undesirable effects on health, safety and cause environmental risks [2]. Traditional plant breeding methods have been used to develop cultivars resistant to various diseases. However, this process is time-consuming and limited availability of genetic resources for most of the crops has left little room to continued improvement by these means. There are many reasons for the limited genetic resources available for breeding [3]. Two of the most important ones are: 1) loss of gene pools occurring during the domestication and breeding of crop plants [4] and 2) many of the natural gene traits that may be beneficial in one plant tissue such as seeds and fruits, may be deleterious in other plant tissues such as vegetative tissues $[5,6]$. Over the past few decades, breeding possibilities have been broadened by genetic engineering and gene transfer technologies including gene mapping and identification of the genome sequences of model plants and crops. Modern technologies such as trancriptomics, proteomics, and metabolomics are now proved to be important in understanding plant metabolic pathways and the role of key genes associated with their regulation. This can facilitate new insights into the complex metabolite neighborhoods that give rise to a given phenotype and may allow discovery of new target genes to modify a given pathway. Such genes can then be subject to new metabolic engineering efforts and applications.

During the last decade, our knowledge repertoire of RNA-mediated functions has been greatly increased with the discovery of small non-coding RNAs which play a central part in a process called RNA silencing. Ironically, the very important phenomenon of co-suppression has recently been recognized as a manifestation of RNA interference (RNAi), an endogenous pathway for negative post-transcriptional regulation. RNAi has revolutionized the possibilities for creating custom "knock-downs" of gene activity. RNAi operates in both plants and animals, and uses double stranded RNA (dsRNA) as a trigger that 
targets homologous mRNAs for degradation or inhibiting its transcription or translation $[7,8]$, whereby susceptible genes can be silenced. This RNA-mediated gene control technology has provided new platforms for developing eco-friendly molecular tools for crop improvement by suppressing the specific genes which are responsible for various stresses and improving novel traits in plants including disease resistance. It has emerged as a method of choice for gene targeting in fungi [9], viruses [10,11], bacteria [12] and plants [13] as it allows the study of the function of hundreds of thousands of genes to be tested [14]. It can silence a gene throughout an organism or in specific tissues [15], offer the versatility to partially silence or completely turn off genes, work in both cultured cells and whole organisms and can selectively silence genes at particular stages of the organism's life cycle [16]. Methods that introduce dsRNA into plant and animal cells have been enormously successful for decreasing cognate gene expression in vivo [17,18]. Due to all these elegant and unique features of RNAi, our review specifically focuses on 1) the current knowledge of RNAi concept and 2) its pathways and induction in plants and explore the possibilities for the applications of this technology in the development of disease resistance plants.

\section{Mechanism of RNAi}

'RNA interference' refers collectively to diverse RNA-based processes that all result in sequence-specific inhibition of gene expression at the transcription, mRNA stability or translational levels. It has most likely evolved as a mechanism for cells to eliminate foreign genes. The unifying features of this phenomena are the production of small RNAs (21-26 nucleotides (nt) that act as specific determinants for down-regulating gene expression [17, $19,20]$ and the requirement for one or more members of the Argonaute family of proteins [21]. RNAi operates by triggering the action of dsRNA intermediates, which are processed into RNA duplexes of 21-24 nucleotides by a ribonuclease III-like enzyme called Dicer [22-24]. Once produced, these small RNA molecules or short interfering RNAs (siRNAs) are incorporated in a multi-subunit complex called RNA induced silencing complex (RISC) $[21,25]$. RISC is formed by a siRNA and an endonuclease among other components. The siRNAs within RISC acts as a guide to target the degradation of complementary messenger RNAs (mRNAs) [21,25]. The host genome codifies for small RNAs called miRNAs that are responsible for endogenous gene silencing. The dsRNAs triggering gene silencing can originate from several sources such as expression of endogenous or transgenic antisense sequences, expression of inverted repeated sequences or RNA synthesis during viral replication [26].
When dsRNA molecules produced during viral replication trigger gene silencing, the process is called virus-induced gene silencing (VIGS) [27]. One interesting feature of RNA silencing in plants is that once it is triggered in a certain cell, a mobile signal is produced and spread through the whole plant causing the entire plant to be silenced [28]. After triggering RNA silencing, the mobile signaling molecules can be relay-amplified by synthesis of dsRNAs on the primary cleavage of product templates or by their cleavage into secondary siRNAs. This amplification leads to the transitory nature of silencing reaction that may spread along the mRNA, though initiated by a locally targeted single siRNA [29] and spreads in both the $5^{\prime}$ and $3^{\prime}$ directions [25]. This bi-directional transition further have been witnessed by a process where both the $5^{\prime}$ and $3^{\prime}$ cleavage products of the initial target RNA act as aberrant mRNAs to trigger dsRNA synthesis [30], and induce secondary silencing reactions. This silencing process is also enhanced by the enzymatic activity of the RISC complex, mediating multiple turnover reactions $[31,25]$. Furthermore, production of the secondary siRNAs leads to enrichment of silencing via its spread from the first activated cell to neighboring cells, and systemically through the system [32]. The cell-to-cell spread can be mediated as passive spread of the small RNAs via plasmodesmata or by the silencing signal complex which is between 27 and $54 \mathrm{kDa}$ [33]. The systemic spread in phloem is mediated by the $24 \mathrm{nt}$ siRNAs [32], unloading of the systemic signal appears to be mediated via plasmodesmata, since it does not spread into meristematic cells [26]. The discovery of RNAbinding protein (PSRP1) in the phloem and its ability to bind $25 \mathrm{nt}$ ssRNA species add further to the argument that siRNAs (24-26 nt) are the key components for systemic silencing signal. The extent of cell-to-cell movement is dependent on the levels of siRNAs produced at the site of silencing initiation, but is independent of the presence of siRNA target transcripts in either source or recipient cells [34].

\section{Methods to Induce RNAi in Plants}

One of the biggest challenges in RNAi research is the delivery of the active molecules that will trigger the RNAi pathway in plants. In this system, a number of methods for delivery of dsRNA or siRNA into different cells and tissue include transformation with dsRNAforming vectors for selected gene(s) by an Agrobacterium mediated transformations $[19,35]$, delivery cognate dsRNA of uidA GUS ( $\beta$-glucuronidase) and TaGLP2a: GFP (green fluorescent protein) reporter genes into single epidermal cells of maize, barley and wheat by particle bombardment [36], introducing a Tobacco rattle virus (TRV)-based vector in tomato plants by infiltration [37], 
delivery of dsRNA into tobacco suspension cells by cationic oligopeptide polyarginine-siRNA complex; infecting plants with viral vectors that produce dsRNA [38] and delivery of siRNA into cultured plant cells of rice, cotton and slash pine for gene silencing by nanosense pulsed laser-induced stress wave (LISW) [40]. Among these the most reliable and commonly used approaches for delivery of dsRNA to plants cells are agroinfiltration, micro-bombardment and VIGS. These are discussed in the following sections.

\subsection{Agroinfiltration}

Agroinfiltration is a powerful method to study processes connected with RNAi. The injection of Agrobacterium carrying similar DNA constructs into the intracellular spaces of leaves for triggering RNA silencing is known as agroinoculation or agroinfiltration [41]. In most cases agroinfiltration is used to initiate systemic silencing or to monitor the effect of suppressor genes. In plants, cytoplasmic RNAi can be induced efficiently by agroinfiltration, similar to a strategy for transient expression of T-DNA vectors after delivery by Agrobacterium tumefaciens. The transiently expressed DNA encodes either an ss- or dsRNA, which is typically a hairpin (hp) RNA. The infiltration of hairpin constructs are especially effective, because their dsRNA can be processed directly to siRNAs, while the constructs expressing ssRNA can also be useful to induce silencing [42-45] and for dissecting the mechanism of gene silencing, especially concerned with its suppressors, systemic silencing signal and also for simple protein purification [42-45]. Besides, they provide a rapid, versatile and convenient way for achieving a very high level of gene expression in a distinct and defined zone.

\subsection{Micro-Bombardment}

In this method, a linear or circular template is transferred into the nucleus by micro-bombardment. Synthetic siRNAs are delivered into plants by biolistic pressure to cause silencing of GFP expression. Bombarding cells with particles coated with dsRNA, siRNA or DNA that encode hairpin constructs as well as sense or antisense RNA, activate the RNAi pathway. The silencing effect of RNAi is occasionally detected as early as a day after bombardment, and it continues up to 3 to 4 days of post bombardment. Systemic spread of the silencing occurred 2 weeks later to manifest in the vascular tissues of the non-bombarded leaves of Nicotiana benthamiana that were closest to the bombarded ones. After one month or so, the loss of GFP expression was seen in non-vascular tissues as well. RNA blot hybridization with systemic leaves indicated that the biolistically delivered siRNAs induced due to de novo formation of siRNAs, which ac- cumulated to cause systemic silencing [29].

\subsection{Virus Induced Gene Silencing (VIGS)}

Modified viruses as RNA silencing triggers are used as a mean for inducing RNA in plants. Different RNA and DNA viruses have been modified to serve as vectors for gene expression [46,47]. Some viruses, such as Tobacco mosaic virus (TMV), Potato virus $X$ (PVX) and TRV, can be used for both protein expression and gene silencing [48-51]. All RNA virus-derived expression vectors will not be useful as silencing vectors because many have potent anti-silencing proteins such as TEV (Tobacco etch virus), that directly interfere with host silencing machinery $[48,52]$. Similarly, DNA viruses have not been used extensively as expression vectors due to their size constraints for movement [53]. However, a non-mobile Maize streak Virus (MSV)-derived vector has been successfully used for long-term production of protein in maize cell cultures [48]. Using viral vectors to silence endogenous plant genes requires cloning homologous gene fragments into the virus without compromising viral replication and movement. This was first demonstrated in RNA viruses by inserting sequences into TMV [54], and then for DNA viruses by replacing the coat protein gene with a homologous sequence [53]. These reports used visible markers for gene silencing phytoene desaturase( $P D S$ ) and chalcone synthase (CHS), providing a measure of the tissue specificity of silencing as these have been involved in carotenoid metabolic pathway. The PDS gene acts on the antenna complex of the thylakoid membranes, and protects the chlorophyll from photooxidation. By silencing this gene, a drastic decrease in leaf carotene content resulted into the appearance of photobleaching symptom $[55,56]$. Similarly, over expression of CHS gene causes an albino phenotype instead of producing the anticipated deep orange color [57]. As a result, their action as a phenotypic marker helps in easy understanding of the mechanism of gene silencing. Table 1 shows some general characteristics for currently available virus-derived gene silencing vectors. Most viruses are plus-strand RNA viruses or satellites, whereas Tomato golden mosaic virus (TGMV) and Cabbage leaf curl virus $(\mathrm{CaLCuV})$ are DNA viruses. Though RNA viruses replicate in the cytoplasm DNA viruses replicate in plant nuclei using the host DNA replication machinery. Both types of viruses induce diffusible, homology-dependent systemic silencing of endogenous genes. However, the extent of silencing spread and the severity of viral symptoms can vary significantly in different host plants and host/virus combinations. With the variety of viruses and the diversity of infection patterns, transmission vectors, and plant defenses it is not surprising that viruses differ with respect to silencing [58]. Because the 
continuing development of virus-based silencing vectors can extend VIGS to economically important plants, it is useful to consider some of the characteristics of successful VIGS vectors.

\section{RNAi in Plant Disease Management}

Despite substantial advances in plant disease management strategies, our global food supply is still threatened by a multitude of pathogens and pests. This changed scenario warrants us to respond more efficiently and effectively to this problem. The situation demands judicious blending of conventional, unconventional and frontier technologies. In this sense, RNAi technology has emerged as one of the most potential and promising strategies for enhancing the building of resistance in plants to combat various fungal, bacterial, viral and nematode diseases causing huge losses in important agricultural crops. The nature of this biological phenomenon has been evaluated in a number of host-pathogen systems and effectively used to silence the action of pathogen. Many of the examples listed below illustrate the possibilities for commercial exploitation of this inherent biological mechanism to generate disease-resistant plants in the future by taking advantage of this approach.

\subsection{Management of Plant Pathogenic Fungi}

RNA-mediated gene silencing (RNA silencing) is used as a reverse tool for gene targeting in fungi. Homologybased gene silencing induced by transgenes (co-suppression), antisense, or dsRNA has been demonstrated in many plant pathogenic fungi, including Cladosporium fulvum [59], Magnaporthae oryzae [60-62], Venturia inaequalis [63], Neurospora crassa [64], Aspergillus nidulans [65], and Fusarium graminearum [9] (Table 1), whether it is suitable for large scale mutagenesis in fungal pathogens remains to be tested. Hypermorphic mechanism of RNA interference implies that this technique can also be applicable to all those plant pathogenic fungi, which are polyploid and polykaryotic in nature, and also offers a solution to the problem where frequent lack of multiple marker genes in fungi is experienced. Simultaneous silencing of several unrelated genes by introducing a single chimeric construct has been demonstrated in case of Venturia inaequalis [63]. HCf-1, a gene that codes for a hydrophobin of the tomato pathogen $C$. fulvum [66], was co-suppressed by ectopic integration of homologous transgenes. Transformation of Cladosporium fulvum with DNA containing a truncated copy of the hydrophobin gene HCf-1 caused co-suppression of hydrophobin synthesis in $30 \%$ of the transformants. The co-suppressed isolates had a hydrophilic phenotype, lower levels of HCf-1 mRNA than wild type and contain multiple copies of the plasmid integrated as tandem re- peats at ectopic sites in the genome. The transcription rate of $H C f-1$ in the co-suppressed isolates was higher in the untransformed strains, which suggested that silencing acted at the post-transcriptional level. This was due to ectopic integration of the transgene next to promoters which initiate transcription to form antisense RNA and that this in turn determines down-regulation of HCf- 1 . But gene silencing was not associated with DNA cytosine methylation [59]. Similarly, the silencing of cgll and $c g l 2$ genes using the cgl2 hairpin construct in Cladosporium fulvum has also been reported [67], though the effect was possibly restricted to highly homolougous genes (exons of cgl 1 and cgl 2 are $87 \%$ identical). However, the less homologus cgl 3 (53\% overall identity to $\mathrm{cgl}$ 2) was not affected as the target specificity always depends upon the actual sequence alignment and more over, short regions of high density that led to unwanted off-targets effects. Such a strategy could be exploited for protecting the consumable products of vegetables and fruits crops from the post-harvest diseases caused by different plant pathogens in future.

Hairpin vector technology resulted in simultaneous high frequency silencing of a green fluorescent protein (GFP) transgene and an endogenous trihydroxynaphthalene reductase gene $(T H N)$ in Venturia inaequalis [63] GFP transgene, acting as easily detectable visible marker while the trihydroxynaphthalene reductase gene (THN) playing role in melanin biosynthesis. High frequency gene silencing was achieved using hairpin constructs for the GFP or the THN genes transferred by Agrobacterium (71 and $61 \%$, respectively). $T H N$-silenced transformants exhibited a distinctive light brown phenotype and maintained the ability to infect apple. Silencing of both genes with this construct occurred at a frequency of $51 \%$ of all the transformants. All 125 colonies silenced for the GFP gene were also silenced for THN [63]. Similarly, multiple gene silencing has been achieved in Cryptococcus

Table 1. RNAi effects on targeted region in some fungal plant pathogens.

\begin{tabular}{lccc}
\hline \multicolumn{1}{c}{ Pathogen } & $\begin{array}{c}\text { Targeted } \\
\text { region }\end{array}$ & Result & References \\
\hline $\begin{array}{l}\text { Magnaporthae } \\
\text { oryzae }\end{array}$ & eGFP & $\begin{array}{c}\text { Sequence specific } \\
\text { degradation of } \\
\text { mRNA }\end{array}$ & {$[60]$} \\
\hline $\begin{array}{l}\text { Cladosporium } \\
\text { falvum }\end{array}$ & cgl 1 and cgl 2 & $\begin{array}{c}\text { Blocking disease } \\
\text { infection spread }\end{array}$ & {$[67]$} \\
$\begin{array}{l}\text { Venturia } \\
\text { inaequalis }\end{array}$ & $\begin{array}{c}\text { Multiple } \\
\text { inverted repeats }\end{array}$ & - & {$[63]$} \\
\hline $\begin{array}{l}\text { Fusarium } \\
\text { graminearum }\end{array}$ & - & - & {$[9]$} \\
\hline $\begin{array}{l}\text { Blumeria } \\
\text { graminis }\end{array}$ & Mlo & Immunity & {$[36]$} \\
\hline
\end{tabular}


neoformans using chimeric hairpin constructs [39] and in plants using partial sense constructs [68]. The first effort towards the systematic silencing of Magnaporthe grisea, a causal organism of rice blast was carried by using the enhanced green florescent protein gene as a model [60]. To assess the ability of RNA species to induce silencing in fungus, plasmid construct expressing sense, antisense and hairpin RNA were introduced into an eGFP-expressing transformants. The fluorescence of eGFP in the transformants was silenced much more efficiently by hairpin RNA of eGFP than by other RNA species. In the silenced transformants, the accumulation of eGFP mRNA was drastically reduced. But not methylation of coding or promoter region was involved. The small interfering RNA molecules of 19-23 nucleotides were observed in both sense and antisense strands of eGFP gene [60]. Later on a protocol for silencing the $m p g 1$ and polyketide synthase-like genes was also developed [9]. $M p g 1$ gene is a hydrophobin gene which is essential for pathogenicity as it act as a cellular relay for adhesion and trigger for the development of appressorium [69]. Their work on this host-pathogen system revealed that they were successfully able to silence the above mentioned genes at varying degrees by pSilent-1-based vectors in $70-90 \%$ of the resulting transformants. Ten to fifteen percent of the silenced transformants exhibited almost "null phenotype". This vector was also efficiently applicable to silence a GFP reporter in another ascomycete fungus Colletotrichum lagenarium [9]. A novel highthroughput approach for gene function analysis using RNAi, which provides an alternative to the gene knock-out by homologous recombination was also described [70]. The authors developed an RNA silencing vector, pSilent-Dual1 (pSD1) that carries two convergent dual promoters, the Aspergillus nidulans tryptophan promoter (PtrpC) and the A. nidulans glyceraldehyde-3phosphate dehydrogenase promoter (Pgpd). Both promoters have been used to drive constitutive gene expression in a large number of filamentous fungi. A multicloning site (MCS) has been inserted between two promoters. The greatest merit of the pSD1 system over others, such as hpRNA or intron spliced hair-pin RNA (ihpRNA) silencing system is that it allows a single step cloning for generation of an RNAi construct. To facilitate efficient screening for silenced transformants, $g f p$ gene was incorporated the into pSD1 system [70]. It allows expression of a chimeric RNA and assessment of gene silencing efficiency by utilizing a recipient strain that produces GFP and therefore, fluoresces green when using epifluorescence microscopy. A main bottleneck of this system is its lower silencing efficiency compared with hpRNA or ihpRNA-expressing RNA-silencing vectors. Formation of dsRNA in the pSD1 system requires physical annealing of two different RNA molecules in the target cells while that in the hpRNA systems is achieved by self-folding of inverted repeats within RNA molecule. The difference in dsRNA formation between the systems can be a major cause of the different silencing efficiencies. The authors generated a series of knock-down mutants of almost all known calcium related genes in the genome of $M$. oryzae and examined for phenotypical defects. Gene knock-down requires relatively short stretches of sequence information. This is a major advantage for phytopathogens for which there is little sequence information available. As RNAi works at the mRNA level, its efficacy is not compromised by the presence of non-transformed nuclei or multicopy genes due to aneuploidy [71]. RNAi causes only a partial reduction, but not a complete loss of, in gene expression. Partial gene suppression is considered a main drawback of RNAi. However, it could be a merit where the effect of an essential gene on a phenotype is of interest. Gene knock-down offers a more convenient and effective tool, especially in combination with an inducible promoter that allows gene expression to be diminished at specific stages during development [72]. Another disadvantage of gene knock-down is, as it requires only a short sequence, that genes other than those targeted might be silenced. This causes unexpected changes in gene expression patterns (off-target effects). Testing for the possibility of off-target effects is simpler for phytopathogen species for which complete genome sequence data are available but remains elusive for those phytopathogens whose genomes have not been sequenced [71]. In another study, RNA interference (RNAi) strategy was used to specifically knockdown 59 individual rice genes encoding putative LRR-RLKs, and a novel rice blast resistance-related gene (designated as OsBRR1) was identified by screening T0 RNAi population using a weakly virulent isolate of Magnaporthe oryzae, Ken 54-04. Wild-type plants (Oryza sativa L. cv. 'Nipponbare') showed intermediate resistance to Ken 54-04, while OsBRR1 suppression plants were susceptible to Ken 54-04 [73]. Furthermore, OsBRR1-overexpressing plants exhibited enhanced resistance to some virulent isolates (97-27-2, 99-31-1 and zhong 10-8-14). OsBRR1 expression was low in leaves and undetectable in roots under normal growth conditions, while its transcript was significantly induced in leaves infected with the blast fungus (Ken 54-04) and was moderately affected by ABA, JA and SA treatment. Overexpression or RNAi suppression of OsBRR1did not cause visible developmental changes in rice plants.

\subsection{Management of Plant Pathogenic Bacteria}

One of the striking examples of bacterial disease management where RNAi showed a remarkable type of gene 
regulation has been documented [12]. They developed a crown gall disease management strategy that targets the process of tumourogensis (gall formation) by initiating RNAi of the iaaM and ipt oncogenes. Expression of these genes is a prerequisite for wild type tumor formation. Transgenic Arabidopsis thaliana and Lycopersicon esculentum transformed with RNAi constructs, targeting iaaM and ipt gene(s) showed resistance to crown gall disease. Transgenic plants generated through this technology contained a modified version of these two bacterial gene(s) required to cause the disease and was the first report to manage a major bacterial disease through RNAi. The extra genes recognize and effectively shut down the expression of the corresponding bacterial gene during infection, thus preventing the spread of infection. The incoming bacteria could not make the hormones needed to cause tumors and plants deficient in silencing were hyper-susceptible to A. tumefaciens [28]. Successful infection relied on a potent anti-silencing state established in tumors whereby siRNA synthesis is specifically inhibited. The procedure can be exploited to develop broadspectrum resistance in ornamental and horticultural plants which are susceptible to crown gall tumorigenesis. This approach can be advocated for the effective management of those pathogens which multiply very rapidly and results in tumor formation such as Albugo candida, Synchytrium endobioticum, Erwinia amylovora etc. The natsiRNA (nat-siRNAATGB2) was strongly induced in Arabidopsis upon infection by Pseudomonas syringae $p v$ tomato and down-regulates a PPRL gene that encodes a negative regulator of the RPS2 disease resistance pathway. As a result, the induction of nat-siRNAATGB2 increases the RPS2-mediated race-specific resistance against $P$. syringae pv tomato in Arabidopsis [74]. Recently, the accumulation of a new class of sRNA, 30 to 40 nucleotides in length, termed long-siRNAs (lsiRNAs), was found associated with $P$. syringae infection. One of these lsiRNAs, AtlsiRNA-1, contributes to plant bacterial resistance by silencing AtRAP, a negative regulator of plant defense [75]. A Pseudomonas bacterial flagellin derived peptide is found to induce the accumulation of miR393 in Arabidopsis. miR393 negatively regulates mRNAs of F-box auxin receptors, resulting in increased resistance to the bacterium ( $P$. syringae), and the overexpression of miR393 was shown to reduce the plant's bacterial titer by 5 -fold [76].

\subsection{Management of Plant Pathogenic Viruses}

Antiviral RNAi technology has been used for viral disease management in human cell lines [77-80]. Such silencing mechanisms (RNAi) can also be exploited to protect and manage viral infections in plants $[19,81]$. The effectiveness of the technology in generating virus resis- tant plants was first reported to PVY in potato, harbouring vectors for simultaneous expression of both sense and antisense transcripts of the helper-component proteinase (HC-Pro) gene [82]. The P1/HC-Pro suppressors from the potyvirus inhabited silencing at a step down stream of dsRNA processing, possibly by preventing the unwinding of duplex siRNAs, or the incorporation into RISC or both [83]. The utilization of RANi technology has resulted in inducing immunity reaction against several other viruses in different plant-virus systems (Table 2). In phyto-pathogenic DNA viruses like geminiviruses

Table 2. Effects of targeted region of RNAi in various plantvirus systems.

\begin{tabular}{|c|c|c|c|}
\hline Host system & Virus & $\begin{array}{l}\text { Targeted } \\
\text { region }\end{array}$ & References \\
\hline $\begin{array}{l}\text { N. benthamiana, } \\
\text { M. esculenta }\end{array}$ & $\begin{array}{c}\text { African cassava } \\
\text { mosaic virus }\end{array}$ & $\begin{array}{l}\text { pds, su, } \\
\text { cyp79d2 }\end{array}$ & [98] \\
\hline Barley, wheat & $\begin{array}{l}\text { Barley stripe } \\
\text { mosaic virus }\end{array}$ & $p d s$ & [99-101] \\
\hline Soybean & $\begin{array}{l}\text { Bean pod } \\
\text { mottle virus }\end{array}$ & $\begin{array}{l}\text { Pds } \\
\text { Actin }\end{array}$ & {$[102-104]$} \\
\hline $\begin{array}{l}\text { Barley, rice, } \\
\text { maize }\end{array}$ & $\begin{array}{c}\text { Brome mosaic } \\
\text { virus }\end{array}$ & $\begin{array}{l}\text { pds, actin } 1, \\
\text { rubisco activase }\end{array}$ & [105] \\
\hline Arabidopsis & $\begin{array}{c}\text { Cabbage leaf } \\
\text { curl virus }\end{array}$ & $g f p, C H 42, p d s$ & {$[56]$} \\
\hline P. sativum & $\begin{array}{c}\text { Pea early } \\
\text { browning virus }\end{array}$ & pspds, uni, kor & [106] \\
\hline N. benthamiana & $\begin{array}{c}\text { Poplar mosaic } \\
\text { virus }\end{array}$ & $g f p$ & [107] \\
\hline $\begin{array}{l}\text { N. benthamiana, } \\
\text { S. tuberosum }\end{array}$ & Potato virus $X$ & $p d s, g f p$ & {$[108,109]$} \\
\hline $\begin{array}{l}\text { Nicotiana } \\
\text { tabacum }\end{array}$ & $\begin{array}{l}\text { Satellite tobacco } \\
\text { mosaic virus }\end{array}$ & Several genes & [110] \\
\hline $\begin{array}{l}\text { N. benthamiana, } \\
\text { N. tabacum }\end{array}$ & $\begin{array}{l}\text { Tobacco } \\
\text { mosaic virus }\end{array}$ & pds, psy & [48] \\
\hline $\begin{array}{l}\text { N. benthamiana, } \\
\text { Arabidopsis, } \\
\text { tomato, Solanum } \\
\text { species, Chilli } \\
\text { pepper, opium } \\
\text { poppy, Aquilegia }\end{array}$ & $\begin{array}{l}\text { Tobacco } \\
\text { rattle virus }\end{array}$ & $\begin{array}{l}\text { Rar1, EDS1, } \\
\text { NPR1/NIM1, } \\
p d s, r b c S, g f p\end{array}$ & [111-115] \\
\hline N. benthamiana & $\begin{array}{l}\text { Tomato bushy } \\
\text { shunt virus }\end{array}$ & $g f p$ & [116] \\
\hline N. benthamiana & $\begin{array}{l}\text { Tomato golden } \\
\text { mosaic virus }\end{array}$ & su, luc & [117] \\
\hline $\begin{array}{l}\text { N. benthamiana, } \\
\text { Lycopersicon } \\
\text { esculentum } \\
\text { N. glutinosa, } \\
\text { N. tabacum }\end{array}$ & $\begin{array}{l}\text { Tomato yellow } \\
\text { leaf curl China } \\
\text { virus-associated } \\
\text { b DNA satellite }\end{array}$ & $\begin{array}{l}\text { pcna, pds, } \\
\text { su, gfp }\end{array}$ & [118] \\
\hline \multicolumn{4}{|c|}{ (Modified after [119]) } \\
\hline
\end{tabular}


non-coding intergenic region of Mungbean yellow mosaic India virus (MYMIV) was expressed as hairpin construct under the control of the $35 \mathrm{~S}$ promoter and used as biolistically to inoculate MYMIV-infected black gram plants and showed a complete recovery from infection, which lasted until senescence [84]. RNAi mediated silencing of geminiviruses using transient protoplast assay where protoplasts were co-transferred with a siRNA designed to replicase (Rep)-coding sequence of African cassava mosaic virus (ACMV) and the genomic DNA of ACMV resulted in 99\% reduction in Rep transcripts and $66 \%$ reduction in viral DNA [85]. It was observed that siRNA was able to silence a closely related strain of ACMV but not a more distantly related virus. More than 40 viral suppressors have been identified in plant viruses [86]. Results from some of the well-studied virus suppressors indicated that suppressors interfere with systemic signaling for silencing [44]. During last few years, the p69 encoded by Turnip yellow mosaic virus has been identified as silencing suppressors that prevented host RDR-dependent secondary dsRNA synthesis [87]. P14 protein encoded by aureus viruses suppressed both virus and transgene-induced silencing by sequestering both long dsRNA and siRNA without size specificity [88]. Multiple suppressors have been reported in Citrus tristeza virus where p20 and coat protein $(C P)$ play important role in suppression of silencing signal and p23 inhibited intracellular silencing [27]. Multiple viral components, viral RNAs and putative RNA replicase proteins were reported for a silencing or suppression of Red clover necrotic mosaic virus [89]. In this case, the RNA silencing machinery deprived of DICER-like enzymes by the viral replication complexes appears to be the cause of the suppression. Pns10 encoded by Rice dwarf virus suppressed local and systemic S-PTGS but not IR-PTGS suggesting that Pns10 also targets an upstream step of dsRNA formation in the silencing pathway [90]. A 273-bp (base pair) sequence of the Arabidopsis miR159 a pre-miRNA transcript expressing amiRNAs was used against the viral suppressor genes P69 and HC-Pro to provide resistance against Turnip yellow mosaic virus and Turnip mosaic virus infection, respectively [91]. In addition, a dimeric construct harboring two unique amiRNAs against both viral suppressors conferred resistance against these two viruses in inoculated Arabidopsis plants. Similarly, a different amiRNA vector was used to target the $2 \mathrm{~b}$ viral suppressor of the $\mathrm{Cu}$ cumber mosaic virus (CMV), a suppressor that interacted with and blocked the slicer activity of AGO1 had also shown to confer resistance to CMV infection in transgenic tobacco [92]. A strong correlation between virus resistance and the expression level of the $2 \mathrm{~b}$-specific amiRNA was shown for individual plant lines. It is evi- dent from above-mentioned reports that the RNA components, such as single strand template RNA, dsRNA and/or siRNA of the silencing pathways are the preferred targets of most viral suppressors. However, plant viruses are known to have evolved a counter-silencing mechanism by encoding proteins that can overcome such resistance $[34,93]$. These suppressors of gene silencing are often involved in viral pathogenicity, mediate synergism among plant viruses and result in the induction of more severe disease. Simultaneous silencing of such diverse plant viruses can be achieved by designing hairpin structures that can target a distinct virus in a single construct [93]. Contrarily, the RNAi system may cause an increase in the severity of viral pathogenesis and/or encode proteins, which can inactivate essential genes in the RNAi machinery [94] that helps them in their replication in the host genome [17]. Transgenic rice plants expressing DNA encoding ORF IV of Rice tungro bacilliform virus (RTBV), both in sense and in anti-sense orientation, resulting in the formation of dsRNA, were generated. Specific degradation of the transgene transcripts and the accumulation of small RNA were observed in transgenic plants. In RTBV-ODs2 line, RTBV DNA levels gradually rose from an initial low to almost $60 \%$ of that of the control at 40 days after inoculation [95]. For the effective control of PRSV and Papaya leaf-distortion mosaic virus (PLDMV), an untranslatable chimeric construct containing truncated PRSV YK CP and PLDMV P-TW-WF CP genes has been transferred into papaya (Carica papaya cv. 'Thailand') by Agrobacterium-mediated transformation via embryogenic tissues derived from immature zygotic embryos of papaya [96]. Based on sequence profile of silencing suppressor protein, HcPro, it was that PRSV-HcPro acts as a suppressor of RNA silencing through micro RNA binding in a dose dependent manner. In planta expression of PRSV-HcPro affects developmental biology of plants, suggesting the interference of suppressor protein in micro RNA-directed regulatory pathways of plants. Besides facilitating the establishment of PRSV, it showed strong positive synergism with other heterologous viruses as well [97].

\subsection{Management of Plant Parasitic Nematodes}

Several major plant parasitic nematodes such as the rootknot (Meloidogyne spp.) and cyst (Heterodera spp.) along with other minor nematodes cause significant damage to important agricultural crops such as legumes, vegetables and cereals in most parts of the world. Therefore, a natural, eco-friendly defense strategy that delivers a cost-effective control of plant parasitic nematodes is needed urgently which is difficult to achieve through conventional approaches. However, the origin of RNAi technology from classical C. elegans studies has shown 
the ways and means to explore the possibilities of this mechanism for protecting plants from nematode damage. In this context, two approaches have been advocated i.e., 1) relies on targeting plant genes that are involved with the infection process and 2) targets the essential genes within the nematode. RNAi can be induced in C. elegans by feeding it dsRNA, hence it was reasoned that expressing hpRNAs containing sequences of vital nematode genes in the host plant might deliver dsRNA to a feeding nematode to incapacitate or kill it.

After the demonstration of gene silencing using siRNA duplexes in the nematode [22], the use of RNAi has rapidly emerged as the technique for plant nematologists to put their efforts, especially for nematode management in agriculture. RNAi-mediated suppression of a gene plays an indispensable role in hampering the nematode development and may adversely affect the progression of pathogenesis in direct or indirect ways. There are accumulating evidences for the efficacy of RNAi in plant parasitic nematode management and a wide range of genes have been targeted for silencing in cyst and rootknot nematode species (Table 3).

RNAi in the context of phyto-parasitic nematodes was used as early as the beginning of this century, when stimulation of oral ingestion by second-stage juveniles of cyst nematodes $H$. glycines, G. pallida [120] and rootknot nematode $M$. incognita was achieved by using octopamine [121]. Later on, resorcinol- and serotonininducing dsRNA uptake by second stage juvenile of $M$. incognita was found to be more effective than octopimine [122]. The genes targeted by RNAi to date are expressed in a range of different tissues and cell types. The ingested dsRNA can silence genes in the intestine [120, 123], female reproductive system [124], sperm [120, 125], and both subventral and dorsal oesophageal glands $[121,122,126,127$,$] . Uptake of dsRNA from the gut is a$ proven route to systemic RNAi in C. elegans. The systemic nature of RNAi in plant parasitic nematodes following ingestion of dsRNA suggests that they share similar uptake and dispersal pathways. However, RNAi of a chitin synthase gene expressed in the eggs of Meloidogyne artiella was achieved by soaking intact eggs contained within their gelatinous matrix in a solution containing dsRNA [128]. The enzyme plays a key role in the synthesis of the chitinous layer in the eggshell. Depletion of its transcript by RNAi led to a reduction in stainable chitin in eggshells and a delay in hatching of juveniles from treated eggs. Similarly, RNAi targeting for cysteine proteinase transcripts did not reduce parasitic population of established nematodes on plants but result into the alteration of their sexual fate in favour of males at 14 days after invasion [120]. On the other hand H. glycines exposed to dsRNA corresponding to a protein
Table 3. RNAi effect on targeted region of plant parasitic nematodes.

\begin{tabular}{|c|c|c|}
\hline Nematode & Targeted region & RNAi effect \\
\hline \multirow[t]{4}{*}{ M. incognita } & Cysteine proteinase & $\begin{array}{l}\text { Delayed development, } \\
\text { Decrease in established } \\
\text { nematodes population }\end{array}$ \\
\hline & Dual oxidase & $\begin{array}{l}\text { Decrease in established } \\
\text { nematodes population and } \\
\text { fecundity. }\end{array}$ \\
\hline & $\begin{array}{l}\text { Splicing factor, } \\
\text { Integrase }\end{array}$ & $\begin{array}{l}\text { Reduction in gall formation } \\
\text { and Female nematode } \\
\text { population }\end{array}$ \\
\hline & $\begin{array}{l}\text { Secreted peptide } \\
16 \mathrm{D} 10\end{array}$ & $\begin{array}{l}\text { Reduction in gall } \\
\text { formation and established } \\
\text { nematode population }\end{array}$ \\
\hline \multirow[t]{7}{*}{ H. glycines } & $\begin{array}{l}\text { Cysteine } \\
\text { proteinase }\end{array}$ & $\begin{array}{l}\text { Increased male: } \\
\text { female ratio. }\end{array}$ \\
\hline & C-type lectin & $\begin{array}{l}\text { Reduction in established } \\
\text { nematodes population }\end{array}$ \\
\hline & $\begin{array}{l}\text { Major sperm } \\
\text { protein }\end{array}$ & Reduction in mRNA level \\
\hline & Aminopeptidase & $\begin{array}{c}\text { Decrease in established } \\
\text { nematodes population and } \\
\text { increase in male: } \\
\text { female ratio. }\end{array}$ \\
\hline & $\beta$-1,4-endoglucanase & $\begin{array}{l}\text { Decrease in established } \\
\text { nematodes population }\end{array}$ \\
\hline & $\begin{array}{c}\text { Pectate lyase, } \\
\text { Chorismate mutase }\end{array}$ & $\begin{array}{l}\text { Increase in male: } \\
\text { female ratio. }\end{array}$ \\
\hline & $\begin{array}{l}\text { Secreted peptide } \\
\text { SYV46 }\end{array}$ & $\begin{array}{l}\text { Decrease in established } \\
\text { nematode population }\end{array}$ \\
\hline \multirow[t]{2}{*}{ G. pallida } & $\begin{array}{l}\text { Cysteine } \\
\text { proteinase }\end{array}$ & $\begin{array}{l}\text { Increase in male: } \\
\text { female ratio. }\end{array}$ \\
\hline & $\begin{array}{l}\text { FMR Famide-like } \\
\text { peptides }\end{array}$ & Motility inhibited \\
\hline \multirow[t]{3}{*}{ G. rostochiensis } & Chitin synthase & Delay in egg hatch \\
\hline & $\beta$-1,4-endoglucanase & $\begin{array}{l}\text { Decrease in established } \\
\text { nematodes population }\end{array}$ \\
\hline & $\begin{array}{l}\text { Secreted amphid } \\
\text { protein }\end{array}$ & $\begin{array}{l}\text { Reduction in invasion } \\
\text { ability to locate and } \\
\text { invade plant roots }\end{array}$ \\
\hline $\begin{array}{l}\text { Heterodera } \\
\text { schachtii }\end{array}$ & $\begin{array}{l}\text { Suc transporter } \\
\text { genes }\end{array}$ & $\begin{array}{l}\text { Reduction of female } \\
\text { nematode development }\end{array}$ \\
\hline \multicolumn{3}{|c|}{ (Modified after [132]) } \\
\hline
\end{tabular}

with homology to C-type lectins did not affect sexual fate, but $41 \%$ fewer nematodes were recovered from the plants. But treatment with dsRNA corresponding to the major sperm protein (MSP) had no effect on nematode development or sexual fate 14 days after treatment. In 
addition to this, reduction in transcript abundance for targeted mRNAs in the infective juvenile and for MSP transcripts when males reached sexual maturity and sperm are produced was observed [120]. In further extension of such types of experiments showed efficient FITC uptake by soaking $M$. incognita, 90-95\% of individuals swallowed the dye when the target was a dual oxidase (an enzyme comprised with a peroxidase domain EF-hands and NADPH oxidase domain and potentially involved in extracellular matrix development). The effect of RNAi was observed when root knot nematode (RKN) juveniles were fed on dual oxidase-derived dsRNA, the reduction in the number and size of established females at 14 and 35 days post- infection with an overall reduction of $70 \%$ in egg production was observed [121]. RNAi has also been induced for a chitin synthase gene that is expressed in the eggshells of $M$. artiella after soaking its developing eggs in a dsRNA [128]. Heterodera schachtii induces syncytial feeding structures in the roots of host plants, and this requires the up-regulation of Suc transporter genes to facilitate increased nutrient flow to the developing structure. Targeting these genes and downregulating them with RNA silencing resulted in a significant reduction of female nematode development [129]. Indeed, tobacco plants transformed with hpRNA constructs against two such root-knot nematode genes have shown such an effect: the target mRNAs in the plant parasitic nematodes were dramatically reduced, and the plants showed effective resistance against the parasite [130]. In another study mRNA abundances of targeted nematode genes were specifically reduced in nematodes feeding on plants expressing corresponding RNAi constructs. Furthermore, this host-induced RNAi of all four nematode parasitism genes led to a reduction in the number of mature nematode females. Although no complete resistance was observed, the reduction of developing females ranged from $23 \%$ to $64 \%$ in different RNAi lines [131]. These observations demonstrate the relevance of the targeted parasitism genes during the nematode life cycle and more importantly, suggest that a viable level of resistance in crop plants may be accomplished in the future by using RNAi technology against cyst nematodes.

\section{Conclusions and Future Prospects}

RNAi and miRNA technologies of gene silencing are newly developed genomics tools that have great advantages over antisense and co-suppression due to their higher silencing efficiency and shorter time requirements for screening. These technologies are particularly useful in conjunction with the practice of gene or pathway discoveries through nutritional genomics, trancriptomics, proteomics and metabolomics in plants to improve hu- man health. The RNA silencing has ability to reduce gene expression in a manner that is highly sequence specific as well as technologically facile and economical. Therefore, this technique has great potential in agriculture specifically for nutritional improvement of plants and the management of mascotous plant diseases. However, the major obstacles hindering its immediate applications include selection of targeting sequences and in the delivery of siRNA. The key issues are: 1) how to select silencing targets for a particular disease, and 2) how to efficiently deliver siRNAs into specific cell types in vivo. Tissue or organ-specific RNAi vectors have already been proven to be useful for targeted gene silencing in specific plant tissues and organs with minimal interference with the normal plant life cycle. New generation RNAi and miRNA vectors have been developed with high silencing accuracy and fewer side effects in plants. Genetic engineering of highly nutritional food crops requires both gene silencing and counter-silencing technologies. Besides, RNAi technology can be considered an eco-friendly, biosafe and ever green technology as it eliminates even certain risks associated with development of transgenic plants carrying first generation constructs (binary vectors and sense and antisense genes). As witnessed from earlier strategies for obtaining viral resistant plants, the expression of protein product from the transgene of interest risked hetero-encapsidation through protein-protein interactions between target and non-target viral gene product, resulted in the development of a non-aphid transmissible strain of Zucchini yellow mosaic virus to aphid-transmissible strain from a transgene expressing a plum pox capsid protein. Since RNAi triggers the formation of dsRNA molecules that target and facilitate the degradation of the gene of interest as well as the transgene itself to avoid problems arising from the synthesis of gene sequences as well as noncoding regions of gene, thus limiting undesirable recombination events. Keeping in view the potentialities of RNAi technology this technology has emerged to combat plant pathogens in the near future as it has already added new dimensions in the chapter of plant disease management. Further, development of vectors that can suppress the RNAi pathway but overexpress transgenes in a tissue-specific manner will revolutionize this field. Such vectors could be based on various viral RNA silencing suppressors and their derivatives. Future directions will focus on developing finely tuned RNAi-based gene silencing vectors that are able to operate in a temporally and spatially controlled manner. However, a better and comprehensive understanding of RNAi would allow the researchers to work effectively and efficiently in order to improve crop plants nutritionally and manage various mascotous intruders of crop plants. 


\section{REFERENCES}

[1] G. W. Chang, H.-W. Lin and S.-K. Chen, "Modeling Characteristics of Harmonic Currents Generated by HighSpeed Railway Traction Drive Converters," Transactions on Power Delivery, IEEE, Vol. 19, No. 2, April 2004, pp. 766-773.

[2] L. Manczinger, Z. Antal and L. Kredics, "Ecophysiology and Breeding of Mycoparasitic Trichoderma Strains (a Review)," Acta Microbiologica et Immunologica Hungarica, Vol. 49, 2002, pp. 1-14.

[3] D. Hoisington, M. Khairallah, T. Reeves, J. M. Ribaut, B. Skovmand, S. Taba and M. Warburton, "Plant Genetic Resources: What can they Contribute toward Increased Crop Productivity," Proceedings of the National Academy of Sciences of the USA, Vol. 96, 1999, pp. 5937-5943.

[4] M. Lee, "Genome Projects and Gene Pools: New Germplasm for Plant Breeding," Proceedings of the National Academy of Sciences of the USA, Vol. 95, 1998, pp. 2001-2004.

[5] V. Frankard, M. Ghislain and M. Jacobs, "Two Feedback-Insensitive Enzymes of the Aspartate Pathway in Nicotiana sylvestris," Plant Physiology, Vol. 99, 1992, pp. 1285-1293.

[6] G. Galili, S. Galili, E. Lewinsohn and Y. Tadmor, "Genetic, Molecular and Genomic Approaches to Improve the Value of Plant Foods and Feeds," Critical Reviews in Plant Sciences, Vol. 21, 2002, pp. 167-204.

[7] M. D. de Bakker, M. Raponi and G. M. Arndr, "RNA-Meditaed Gene Silencing in Non-Pathogenic and Pathogenic Fungi," Current Opinion in Microbiology, Vol. 5, 2002, pp. 323-329.

[8] R, Almeida and R. C. Allshire, "RNA Silencing and Genome Regulation," Trends in Cell Biology, Vol. 15, 2005, pp. 251-258.

[9] H. Nakayashiki, "RNA Silencing in Fungi: Mechanisms and Applications," Federation of European Biochemical Societies Letters, Vol. 579, 2005, pp. 5950-5970.

[10] D. C. Baulcombe, "RNA silencing in Plants," Nature, Vol. 431, 2004, pp. 356-363.

[11] S. H. Wani and G. S. Sanghera, "Genetic Engineering for Viral Disease Management in Plants," Notulae Scientia Biologicae, Vol. 2, 2010, pp. 20-28.

[12] M. A. Escobar, E. L. Civerolo, K. R. Summerfelt and A.M Dandekar, "RNAi-Mediated Oncogene Silencing Confers Ressitance to Crown Gall Tumorigenesis," Proceedings of the National Academy of Sciences USA, Vol. 98, 2001, pp. 13437-13442.

[13] P. Brodersen and O. Voinnet, "The Diversity of RNA Silencing Pathways in Plants," Trends in Genetics, Vol. 22, 2006, pp. 268-280.

[14] M. R. Godge, A. Purkayastha, I. Dasgupta and P. P. Kumar, "Virus-Induced Gene Silencing for Functional Analysis of Selected Genes," Plant Cell Reporter, Vol. 27, 2008, pp. 209-219.

[15] S. M. Shahinul Islam, T. Miyazaki, F. Tanno and K. Itoh, "Dissection of Gene Function by RNA Silencing," Plant
Biotechnology, Vol. 22, 2005, pp. 443-446.

[16] O. Milhavet, D. S. Gary and M. P. Mattson "RNA Interference in Biology and Medicine," Pharmacological Reviews, Vol. 55, 2003, pp. 629-648.

[17] G. J. Hannon, "RNA Interference," Nature, Vol. 418, 2002, pp. 244-251.

[18] H. Vaucheret, F. Vazquez, P. Crete, and D. P. Bartel, "The Action of ARGONAUTE1 in the miRNA Pathway and Its Regulation by the miRNA Pathway are Crucial for Plant Development," Genes and Development, Vol. 18, 2004, pp. 187-1197.

[19] P. M. Waterhouse, M. B. Wang and T. Lough, "Gene Silencing as an Adaptive Defense against Viruses," $\mathrm{Na}$ ture, Vol. 411, 2001, pp. 834-842.

[20] A. S. Pickford and C. Cogoni, "RNA-Mediated Gene Silencing," Cellular and Molecular Life Science, Vol. 60, 2003, pp. 871-882.

[21] S. M. Hammond, E. Bernstein, D. Beach and G. J. Hannon, "An RNA-Directed Nuclease Mediates Post-Transcriptional Gene Silencing in Drosophila Cells," Nature, Vol. 404, 2000, pp. 293-296.

[22] A. Fire, S. Xu, M. K. Montgomery, S. A. Kostas, S. E .Driver and C. C. Mello, "Potent and Specific Genetic Interference by Double-Stranded RNA in Caenorhabditis elegans," Nature, Vol. 391, 1998, pp. 806-811.

[23] E. Bernstein, A. A. Caudy, S. M. Hammond and G. J. Hannon, "Role for a Bidentate Ribonuclease in the Initiation Step of RNA Interference," Nature, Vol. 409, 2001, pp. 363-366.

[24] S. V. Wesley, C. A. Helliwell, N. A. Smith, M. B. Wang, D. T. Rouse, Q. Liu, P. S. Gooding, S. P. Singh, D. Abbott, P. A. Stoutjesdijk, S. P. Robinson, A. P. Gleave, A. G. Green, and P. Waterhouse, "Construct Design for Efficient, Effective and High-Throughput Gene Silencing in Plants," Plant Journal, Vol. 27, 2001, pp. 581-590.

[25] G. Tang, B. J. Reinhart, D. Bartel and P. D. Zamore, "A Biochemical Framework for RNA Silencing in Plants," Genes and Development, Vol.17, 2003, pp. 49-63.

[26] O. Voinnet, "Non-Cell Autonomous RNA Silencing," Federation of European Biochemical Societies Letters, Vol. 579, 2005, pp. 5858-5871.

[27] R. Lu, A. M. Martin-Hernandez, J. R. Peart, I. Malcuit and D. C. Baulcombe, "Virus Induced Gene Silencing in Plants," Methods, Vol. 30, 2003, pp. 296-303.

[28] P. Dunoyer, C. Himber, V. Ruiz-Ferrer, A. Alioua and O. Voinnet, "Intra- and Intercellular RNA Interference in Arabidopsis thaliana Requires Components of the MicroRNA and Heterochromatic Silencing Pathways," Nature Genetics, Vol. 39, 2007, pp. 848-856.

[29] U. Klahre, P. Crete, S. A. Leuenberger, V. A. Iglesias and F. Meins, "High Molecular Weight RNAs and Small Interfering RNAs Induce Systemic Post Transcriptional Gene Silencing in Plants," Proceedings of the National Academy of Sciences of the USA, Vol. 99, 2002, pp. 11981-11986.

[30] A. J. Herr, A. Molnar, A. Jones and D. C. Baulcombe, 
"Defective RNA Processing Enhances RNA Silencing and Influences Flowering of Arabidopsis," Proceedings of the National Academy of Sciences of the USA, Vol. 103, 2006, pp. 14994-15001.

[31] G. Hutvagner and P. D. Zamore, "A microRNA in a Multiple-Turnover RNAi Enzyme Complex," Science, Vol. 297, 2002, pp. 2056-2060.

[32] C. Himber, P. Dunoyer, G. Moissiard, C. Ritzenthaler and O. Voinnet, "Transitivity Dependent and Independent Cell-to-Cell Movement of RNA Silencing," The EMBO Journal, Vol. 22, 2003, pp. 4523-4533

[33] K. Kobayashi and P. Zambryski, "RNA Silencing and Its Cell-to-Cell Spread during is Embryogenesis," The Plant Journal, Vol. 50, 2007, pp. 597-604.

[34] F. Li, and S. W. Ding, "Virus Counter Defense: Diverse Strategies for Evading the RNA Silencing Immunity," Annual Review of Microbiology, Vol. 60, 2006, pp. 503531.

[35] C. F. Chuang and E. M. Meyerowtiz, "Specific and Heritable Genetic Interference by Double-Stranded RNA in Arabidopsis thaliana," Proceedings of the National Academy of Sciences of the USA, Vol. 97, 2000, pp. 9854990.

[36] P. Schweizer, J. Pokorny, P. Schulze-Lefert and R Dudler, "Double Stranded RNA Interference with Gene Functions at the Single Cell in Cereals," The Plant Journal, Vol. 24, 2000, pp. 895-903.

[37] Y. L. Liu, M. Schiff and S. P. Dinesh-Kumar, "Virus Induced Gene Silencing in Tomato," The Plant Journal, Vol. 31, 2002a, pp. 777-786.

[38] T. Dalmay, A. J. Hamilton, E. Mueller and D. C. Baulcombe, "Potato Virus X Amplicons in Arabidopsis Mediate Genetic and Epigenetic Gene Silencing," The Plant Cell, Vol. 12, 2000, pp. 369-380.

[39] H. Liu, T. R. Cottrell, L. M. Pierini, W. E. Goldman and T. L. Doering, "RNA Interference in the Pathogenic Fungus Cryptococcus neoformans," Genetics, Vol. 160, 2002b, pp. 463-470.

[40] W. Tang, D. A. Weidner, B. Y. Hu, R. J. Newton and X. $\mathrm{Hu}$, "Efficient Delivery of Small Interfering RNA to Plant Cells by a Nanosecond Pulsed Laser-Induced Wave for Post Transcriptional Gene Silencing," Plant Science, Vol. 171, 2006, pp. $375-81$.

[41] J. M. Hilly, and Z. Liu, "An Overview of Small RNAs," In: C. L. Bassett, Ed., Regulation of Gene Expression in Plants, Springer-Verlag, Berlin, 2007, pp. 123-147.

[42] L. K. Johansen, and J. C. Carrington, "Silencing on the Spot. Induction and Suppression of RNA Silencing in the Agrobacterium-Mediated Transient Expression System," Plant Physiology, Vol. 126, 2001, pp. 930-938.

[43] O. Voinnet, "RNA Silencing as a Plant Immune System against Viruses," Trends in Genetics, Vol. 17, 2001, pp. 449-459.

[44] S. Mlotshwas, O. Voinnet, M. F. Mette, M. Matzke, H. Vaucheret, S. W. Ding, G. Pruss and G. B. Vance, "RNA Silencing and Its Mobile Silencing Signal," The Plant
Cell, Vol. 14, 2002, pp. 289-301.

[45] F. Tenllado, B. Martinez-Garcia, M. Vargas and J. R. Diaz-Ruiz, "Crude Extracts of Bacterially Expressed dsRNA can be Used to Protect Plants against Virus Infection," BMC Biotechnology, Vol. 3, 2003, pp. 3-14.

[46] M. Timmermans, O. Das and J. Messing, "Geminivirus and Their Uses as Extrachromosomeal Replicons," Annual Review of Plant Physiology, Vol. 45, 1994, pp. 79112.

[47] G. P. Pogue, J. A. Lindbo, S. J. Garger and W. P. Fitzmaurice, "Making an Ally from an Enemy: Plant Virology and the New Agriculture," Annual Review of Phytopathology, Vol. 40, 2002, pp. 45-74.

[48] M. H. Kumagai, J. Donson, G. della-Cioppa, D. Harvey, K. Hanley and L. K. Grill, "Cytoplasmic Inhibition of Carotenoid Biosynthesis with Virus-Derived RNA," Proceedings of the National Academy of Sciences of the USA, Vol. 92, 1995, pp. 1679-1683.

[49] S. M. Angell and D. C. Baulcombe, "Technical Advance: Potato Virus X Amplicon Mediated Silencing of Nuclear Genes," The Plant Journal, Vol. 20, 1999, pp. 357-362.

[50] S. A. MacFarlane, and A. H. Popovich, "Efficient Expression of Foreign Proteins in Roots from Tobravirus Vectors," Virology, Vol. 267, 2000, pp. 29-35.

[51] A. C. Mallory, G. Parks, M. W. Endres, D. Baulcombe and L. H. Bowman, "The Amplicon-Plus System for High- Level Expression of Transgenes in Plants," Nature Biotechnogy, Vol. 20, 2002, pp. 622-625.

[52] K. E. Palmer and E. P. Rybicki, "Investigation of the potential of maize streak virus to act as an infectious gene vector in maize plants," Archives of Virology, Vol. 146, 2001, pp. 1089-1104.

[53] S. Kjemtrup, K. S. Sampson, C. G. Peele, L. V. Nguyen and M. A. Conkling, "Gene Silencing from Plant DNA Carried by a Geminivirus,” Plant Journal, Vol. 14, 1998, pp. 91-100.

[54] M. J. Dallwitz and E. J. Zurcher, "Plant Viruses Online," In: A. A. Brunt, K. Crabtree, M. J. Dallwitz, A. J. Gibbs, L. Watson and E. J. Zurcher, Ed., Descriptions and Lists from the VIDE Database, CAB International, UK, 1996, pp. 1484.

[55] Q. Liu, S. P. Singh, and A. G. Green, "High-Stearic and High-Oleic Cottonseed Oils Produced by Hairpin RNAMediated Post-Transcriptional Gene Silencing," Plant Physiology, Vol. 129, 2002c, pp. 1732-1743.

[56] M. A. Turnage, N. Muangsan, C. G. Peele and D. Robertson, "Geminivirus-Based Vectors for Gene Silencing in Arabidopsis," The Plant Journal, Vol. 30, 2002, pp. 107-117.

[57] C. Cogoni, N. Romano and G. Macino, "Suppression of Gene Expression by Homologous Transgenes," Antonie Leeuwenhoek International Journal of General Molecular Microbiology, Vol. 65, 1994, pp. 205-209.

[58] P. Y. Teycheney and M Tepfer, "Virus Specific Spatial Differences in the Interference with Silencing of the chs-A Gene in Non-Transgenic Petunia," Journal of Gen- 
eral Virology, Vol. 82, 2001, pp. 1239-1243.

[59] W. Hamada and P. D. Spanu, "Co-Suppression of the Hydrophobin Gene Hcf-1 is Correlated with Antisense RNA Biosynthesis in Cladosporium fulvum," Molecular and General Genetics, Vol. 259, 1998, pp. 630-638.

[60] N. Kadotani, H. Nakayashiki, Y. Tosa and S. Mayama, "RNA Silencing in the Pathogenic Fungus Magnaporthe oryzae," Molecular Plant-Microbe Interaction, Vol. 16, 2003, pp. 769-776.

[61] J. A. Kim, K. Cho, R. Singh, Y. H. Jung, S. H. Jeong, S. H. Kim, J. E. Lee, Y. S. Cho, G. K. Agrawal, R. Rakwal, S. Tamogami, B. Kersten, J. S. Jeon, G. An and N. S. Jwa, "Rice OsACDR1 (Oryza sativa Accelerated Cell Death and Resistance 1) is a Potential Positive Regulator of Fungal Disease Resistance," Molecules and Cells, Vol. 30, 2009, pp. 431-439.

[62] L. Chen, K. Shiotani, T. Togashi, D. Miki, M. Aoyama, H. L. Wong, T. Kawasaki and K. Shimamoto, "Analysis of the Rac/Rop Small GTPase Family in Rice: Expression, Subcellular Localization and Role in Disease Resistance," Plant and Cell Physiology, Vol. 51, 2010, pp. 585-595.

[63] A. Fitzgerald, J. A. Van Kha and K. M. Plummer, "Simultaneous Silencing of Multiple Genes in the Apple Scab Fungus Venturia inaequalis, by Expression of RNA with Chimeric Inverted Repeats," Fungal Genetics and Biology, Vol. 41, 2004, pp. 963-971.

[64] M. Goldoni, G. Azzalin, G. Macino and C. Cogoni, "Efficient Gene Silencing by Expression of Double Stranded RNA in Neurospora crassa," Fungal Genetics and Biology, Vol. 41, 2004, pp. 1016-1024.

[65] T. M. Hammond and N. P. Keller, "RNA Silencing in Aspergillus nidulans is Independent of RNA-Dependent RNA polymerase," Genetics, Vol. 169, 2005, pp. 607-617.

[66] P. Spanu, "HCf-1, a Hydrophobin from the Tomato PathoGen Cladosporium fulvum," Gene, Vol. 93, 1997, pp. 89-96.

[67] G. C. Segers, W. Hamada, R. P. Oliver and P. D. Spanu, "Isolation and Characteristaion of Five Different Hydrophobin-Encoding cDNA from the Fungal Tomato Pathogen Cladosporium fulvum," Molecular and General Genetics, Vol. 261, 1999, pp. 644-652.

[68] J. C. Abbott, A. Barakate, G. Pincon, M. Legrand, C. Lapierre, I. Mila, W. Schuch and C. Halpin, "Simultaneous Suppression of Multiple Genes by Single Transgenes. Down-Regulation of Three Unrelated Lignin Biosynthetic Genes in Tobacco," Plant Physiology, Vol. 128, 2002, pp. 844-853.

[69] N. J. Talbot, M. J. Kershaw, G. E. Wakley, O. M. H. de Vries, J. G. H. Wessels and J. E. Hamer, "MPG1 Encodes a Fungal Hydrophobin Involved in Surface Interactions during Infection-Related Development of Magnaporthe grisea," Plant Cell, Vol. 8, 1996, pp. 985-999.

[70] Q. B. Nguyen, N. Kadotani, S. Kasahara, Y. Tosa, S. Mayama and H. Nakayashiki, "Systematic Functional Analysis of Calcium-Signalling Proteins in the Genome of the Rice-Blast Fungus, Magnaporthe oryzae, Using a High-Throughput RNA-Silencing System," Molecular
Microbiology, Vol. 68, 2008, pp. 1348-1365.

[71] R. J. Weld, K. M. Plummer, M. A. Carpenter, and H. J. Ridgway, "Approaches to Functional Genomics in Filamentous Fungi," Cell Research, Vol. 16, 2006, pp. 31-44.

[72] H. Nakayashiki and Q. B. Nguyen, "RNA Interference: Roles in Fungal Biology," Current Opinion in Microbiology, Vol. 11, 2008, pp. 1-9.

[73] H. Peng, Q. Zhang, Y. Li, C. Lei, Y. Zhai, X. Sun, D. Sun, Y. Sun and T. Lu, "A Putative Leucine-Rich Repeat Receptor Kinase, OsBRR1, is Involved in Rice Blast Resistance," Planta, Vol. 230, 2009, pp. 377-385.

[74] S. Katiyar-Agarwal, R. Morgan, D. Dahlbeck, O. Borsani, J. A. Villegas, J. Zhu, B. J. Staskawicz and H. Jin, "A Pathogen-Inducible Endogenous siRNA in Plant Immunity," Proceedings of the National Academy of Sciences of the USA, Vol. 103, 2006, pp. 47-52.

[75] S. Katiyar-Agarwal, S. Gao, A. Vivian-Smith and H. Jin, "A Novel Class of Bacteria-Induced Small RNAs in Arabidopsis," Genes and Development, Vol. 21, 2007, pp. 3123-3134.

[76] L. Navarro, P. Dunoyer, F. Jay, B. Arnold, N. Dharmasini, M. Estelle, O. Vionnet and J. D. Jones, "A Plant miRNA Contributes to Antibacterial Resistance by Repressing Auxin Signaling," Science, Vol. 312, 2006, pp. 436-439.

[77] V. Bitko and S. Barik, "Phenotypic Silencing of Cytoplasmic Genes with Sequence Specific Double Stranded Short Interfering RNA and Its Applications in the Reverse Genetics of Wild Type Negative Strand RNA Virus," BMC Microbiology, Vol. 1, 2001, pp. 34-44.

[78] L. Gitlin, S. Karelsky, and R. Andino, "Short Interference Confers Intracellular Antiviral Immunity in Human Cells," Nature, Vol. 4, 2002, pp. 418-430.

[79] J. M. Jacque, K. Triques and M. Stevenson, "Modulation of HIV-1 Replication by RNA Interference," Nature, Vol. 418, 2002, pp. 435-438.

[80] C. D. Novina, M. F Murray, D. M. Dykxhoorn, P. J. Beresford, J. Riess, S. K. Lee, R. G. Collman, J. Lieberman, P. Shanker and P. A. Sharp, "siRNA-Directed Inhibition of HIV-1 Infection," Nature Mediterranean, Vol. 8, 2002, pp. 681-686.

[81] E. Ullu, A. Djikeng, H. Shi, and C. Tschudi, "RNA Interference: Advances and Questions," Philosophical Transactions of the Royal Society of London British Biological Science, Vol. 29, 2002, pp. 65-70.

[82] P. M. Waterhouse, M. W. Graham and M. B. Wang, "Virus Resistance and Gene Silencing in Plants can be Induced by Simultaneous Expression of Sense and Antisense RNA," Proceedings of the National Academy of Sciences of the USA, Vol. 95, 1998, pp. 13959-13964.

[83] E. J. Chapman, A. I. Prokhnevsky, K. Gopinath, V. V. Dolja and J. C. Carrington, "Viral RNA Silencing Suppressors Inhibit the micro-RNA Pathway at an Interphase Step," Genes and Development, Vol. 18, 2004, pp. 11791186.

[84] M. Pooggin, P. V. Shivaprasad, K. Veluthambi and T. Hohn, "RNAi Targetting of DNA Viruses," Nature Bio- 
technology, Vol. 21, 2003, pp. 131-32.

[85] R. Vanitharani, P. Chellappan and C. M. Fauquet, "Short Interfering RNA-Mediated Interference of Gene Expression and Viral DNA Accumulation in Cultured Plant Cells," Proceedings of the National Academy of Sciences of the USA, Vol. 100, 2003, pp. 9632-9636.

[86] V. Ruiz-Ferrer and O. Voinnet, "Viral Suppression of RNA Silencing: 2b Wins the Golden Fleece by Defeating Argonaute," Bioassays, Vol. 29, 2007, pp. 319-323.

[87] J. Chen, W. X. Li, D. Xie, J. R. Peng, and S. W. Ding, "Viral Virulence Protein Suppresses RNA Silencing-Mediated Defense but Upregulates the Role of microRNA in Host Gene Regulation," Plant Cell, Vol. 16, No. 5, 2004, pp. 1302-1313.

[88] Z. Merai, Z. Kerenyi, A. Molnar, E. Barta, A. Valcozi, G. Bistray, Z. Havelda, J. Burgyan and D. Silhavy, "Aureusvirus P14 is an Efficient RNA Silencing Suppressor that Binds Double Stranded RNAs without Size specificity," Journal of Virology, Vol. 79, 2005, pp. 7217- 7226.

[89] A. Takeda, M. Tsukuda, H. Mizumoto, K. Okamoto, M. Kaido, K. Mise and T. Okuno, "A Plant RNA Virus Suppressor RNA Silencing through RNA Replication," The EMBO Journal, Vol. 24, 2005 pp. 3147-3157.

[90] X. Cao, P. Zhou, X. Zhang, S. Zhu, X. Zhong, Q. Xiao, B. Ding and Y. Li, "Identification of an RNA Silencing Suppressors from a Plant Double Stranded RNA Virus," Journal of Virology, Vol. 79, 2005, pp. 13018-13027.

[91] Q. W. Niu, S. S. Lin, J. L. Reyes, K. C. Chen, H. W. Wu, S. D. Yeh and N. H. Chua, "Expression of Artificial microRNAs in Transgenic Arabidopsis thaliana Confers Virus Resistance," Nature Biotechnology, Vol. 24, 2006, pp. 1420-1428.

[92] J. Qu, J. Ye and R. X. Fang, "Artificial microRNA-Mediated Virus Resistance in Plants," Journal of Virology, Vol. 81, 2007, pp. 6690-6699.

[93] J. A. Díaz-Pendón and S. W. Ding, "Direct and Indirect Roles of Viral Suppressors of RNA Silencing in Pathogenesis," Annual Review of Phytopathology, Vol. 46, 2008, pp. 303-326.

[94] S. M. Elbashir, W. Lendeckel, and T. Tuschl, "RNA Interference is Mediated by 21 and 22-Nucleotide RNAs," Genes and Development, Vol. 15, 2001, pp. 188-200.

[95] H. Tyagi, S. Rajasubramaniam, M. V. Rajam and I. Dasgupta, "RNA Interference in Rice against Rice Tungro Bacilliform Virus Results in Its Decreased Accumulation in Inoculated Rice Plants," Transgenic Research, Vol. 17, 2008, pp. 897-904.

[96] Y. J. Kung, T. A. Yu, C. H. Huang, H. C. Wang, S. L. Wang and S. D. Yeh, "Generation of Hermaphrodite Transgenic Papaya Lines with Virus Resistance via Transformation of Somatic Embryos Derived from Adventitious Roots of in vitro shoots," Transgenic Research, 2009, in press.

[97] S. K. Mangrauthia, P. Singh and S. Praveen, "Genomics of Helper Component Proteinase Reveals Effective Strategy for Papaya Ringspot Virus Resistance," Molecular Biotechnology, Vol. 44, 2010, pp. 22-29.
[98] I. B. Fofana, A. Sangare, R. Collier, C. Taylor and C. M. Fauquet, "A Geminivirus-Induced Gene Silencing System for Gene Function Validation in Cassava," Plant Molecular Biology, Vol. 56, 2004, pp. 613-624.

[99] S. Holzberg, P. Brosio, C. Gross and G. P. Pogue, "Barley Stripe Mosaic Virus-Induced Gene Silencing in a Monocot Plant," Plant Journal, Vol. 30, 2002, pp. 315327.

[100] S. R. Scofield, L. Huang, A. S. Brandt and B. S. Gill, "Development of a Virus-Induced Gene Silencing System for Hexaploid Wheat and Its Use in Functional Analysis of the Lr21-Mediated Leaf Rust Resistance Pathway," Plant Physiology, Vol. 138, 2005, pp. 2165-2173.

[101] C. Cakir and M. Tör, "Factors Influencing Barley Stripe Mosaic Virus-Mediated Gene Silencing in Wheat," Physiological and Molecular Plant Pathology, Vol. 74, 2010, pp. 246-253.

[102] C. Zhang and S. A. Ghabrial, "Development of Bean Pod Mottle Virus-Based Vectors for Stable Protein Expression and Sequence-Specific Virus-Induced Gene Silencing in Soybean," Virology, Vol. 344, 2006, pp. 401-411.

[103] C. Zhang, C. Yang, S. A. Whitham and J. H. Hill "Development and Use of an Efficient DNA-Based Viral Gene Silencing Vector for Soybean," Molecular Plant Microbe Interaction, Vol. 22, 2009, pp. 123-131.

[104] C. Zhang, J. D. Bradshaw, S. A. Whitham and J. H. Hill "The Development of an Efficient Multi-Purpose BPMV Viral Vector Set for Foreign Gene Expression and RNA Silencing," Plant Physiology, 2010, in press.

[105] X. S. Ding, W. L. Schneider, S. R. Chaluvadi, R. M. Rouf Mian and R. S. Nelson, "Characterization of a Brome Mosaic Virus Strain and Its Use as a Vector for Gene Silencing in Monocotyledonous Hosts," Molecular Plant Microbe Interaction, Vol. 19, 2006, pp. 1229-1239.

[106] G. D. Constantin, B. N. Krath, S. A. MacFarlane, M. Nicolaisen, I. E. Johansen and O. S. Lund, "Virus-Induced Gene Silencing as a Tool for Functional Genomics in a Legume Species," Plant Journal, Vol. 40, 2004, pp. 622-631.

[107] M. Naylor, J. Reeves, J. I. Cooper, M. L. Edwards and H. Wang, "Construction and Properties of a Gene Silencing Vector Based on Poplar Mosaic Virus (Genus Carlavirus)," Journal of Virology Methods, Vol. 124, 2005, pp. 27-36.

[108] M. T. Ruiz, O. Voinnet and D. C. Baulcombe, "Initiation and Maintenance of Virus-Induced Gene Silencing," Plant Cell, Vol. 10, 1998, pp. 937-946.

[109] O. Faivre-Rampant, E. M. Gilroy, K. Hrubikova, I. Hein, S. Millam, G. J. Loake, P. Birch, M. Taylor and C. Lacomme, "Potato Virus X-Induced Gene Silencing in Leaves and Tubers of Potato," Plant Physiology, Vol. 134, 2004, pp. 1308-1316.

[110] V. V. Gossele, I. I. Fache, F. Meulewaeter, M. Cornelissen and M. Metzlaff, "SVISS-a Novel Transient Gene Silencing System for Gene Function Discovery and Validation in Tobacco," The Plant Journal, Vol. 32, 2002, pp. 
859- 866.

[111]F. Ratcliff, A. M. Martin-Hernandez and D. C. Baulcombe, "Tobacco Rattle Virus as a Vector for Analysis of gene Functions by Silencing," Plant Journal, Vol. 25, 2001, pp. 237-245.

[112] G. Brigneti, A. M. Martin-Hernandez, H. Jin, J. Chen, D. C. Baulcombe, B. Baker, and J. D. Jones, "Virus-Induced Gene Silencing in Solanum Species," The Plant Journal, Vol. 39, 2004, pp. 264-272.

[113] E. Chung, E. Seong, Y. C. Kim, E. J. Chung, S. K. Oh, S. Lee, J. M. Park, Y. H. Joung and D. Choi, "A Method of High Frequency Virus Induced Gene Silencing in Chili Pepper Capsicum annuum L. cv. Bukang)," Molecular Cell, Vol. 17, 2004, pp. 377-380.

[114] L. C. Hileman, S. Drea, G. Martino, A. Litt and V. F. Irish, "Virus Induced Gene Silencing is an Effective Tool for Assaying Gene Function in the Basal Eudicot Species Papaver somniferum (Opium Poppy)," The Plant Journal, Vol. 44, 2005, pp.334-341.

[115] B. Gould and E. M. Kramer, "Virus-Induced Gene Silencing as a Tool for Functional Analyses in the Emerging Model Plant Aquilegia (columbine, Ranunculaceae)," BMC Plant Methods, Vol. 12, 2007, pp. 6.

[116] H. Hou and W. Qiu, “A Novel Co-Delivery System Consisting of a Tomato Bushy Stunt Virus and a Defective Interfering RNA for Studying Gene Silencing," Journal of Virology Methods, Vol. 111, 2003, pp. 37-42.

[117] C. Peele, C.V. Jordan, N. Muangsan, M. Turnage, E. Egelkrout, P. Eagle, L. Hanley-Bowdoin and D. Robertson, "Silencing of a Meristematic Gene Using Geminivirus-Derived Vectors," Plant Journal, Vol. 27, 2001, pp. 357-366.

[118]X. Tao and X. Zhou, "A Modified Viral Satellite DNA that Suppresses Gene Expression in Plants," The Plant Journal, Vol. 38, 2004, pp. 850-860.

[119] M. R. Godge, A. Purkayastha, I. Dasgupta and P. P. Kumar, "Virus-Induced Gene Silencing for Functional Analysis of Selected Genes," Plant Cell Reporter, Vol. 27, 2008, pp. 209-219.

[120] P. E. Urwin, C. J. Lilley and H. J. Atkinson, "Ingestion of Double-Stranded RNA by Pre-Parasitic Juvenile Cyst Nematodes Leads to RNA Interference," Molecular Plant-Microbe Interactions, Vol. 15, 2002, pp. 747-752.

[121] M. Bakhetia, W. Charlton, H. J. Atkinson and M. J. McPherson, "RNA Interference of Dual Oxidase in the Plant Nematode Meloidogyne incognita," Molecular PlantMicrobe Interaction, Vol. 18, 2005, pp. 1099-1106.

[122] M. N. Rosso, M. P. Dubrana, N. Cimbolini, S. Jaubert and P. Abad, "Application of RNA Interference to RootKnot Nematode Genes Encoding Esophageal Gland Pro- teins," Molecular Plant-Microbe Interactions, Vol. 18, 2005, pp. 615-620.

[123] J. Shingles, C. J. Lilley, H. J. Atkinson and P. E. Urwin, "Meloidogyne incognita: Molecular and Biochemical Characterization of a Cathepsin L Cysteine Proteinase and the Effect on Parasitism Following RNAi," Experimental Parasitology, Vol. 115, 2007, pp. 114-120.

[124] C. J. Lilley, S. A. Goodchild, H. J. Atkinson and P. E. Urwin, "Cloning and Characterization of a Heterodera glycines Minopeptidase cDNA," International Journal of Parasitology, Vol. 35, 2005, pp. 1577-1585.

[125] R. M. Steeves, T. C. Todd, J. S. Essig and H. N. Trick, "Transgenic Soybeans Expressing siRNAs Specific to a Major Sperm Protein Gene Suppress Heterodera glycines Reproduction," Functional Plant Biology, Vol. 33, 2006, pp. 991-999.

[126] Q. Chen, S. Rehman, G. Smant and J. T. Jones, "Functional Analysis of Pathogenicity Proteins of the Potato Cyst Nematode Globodera rostochiensis Using RNAi," Molecular Plant-Microbe Interactions, Vol. 18, 2005, pp. 621-625.

[127] G. Huang, R. Allen, E. L. Davis, T. J. Baum and R. S. Hussey, "Engineering Broad Root-Knot Resistance in Transgenic Plants by RNAi Silencing of a Conserved and Essential Root-Knot Nematode Parasitism Gene," Proceedings of the National Academy of Sciences of the USA Vol. 103, 2006, pp. 4302-14306.

[128] E. Fanelli, M. Di Vito, J. T. Jones and C. De Giorgi, "Analysis of Chitin Synthase Function in a Plant Parasitic Nematode, Meloidogyne artiellia, Using RNAi," Gene, Vol. 349, 2005, pp. 87-95.

[129] Y. Hoffman, C. Aflalo, A. Zarka, J. Gutman, T.Y. James, and S. Boussiba, "Isolation and characterization of a novel chytrid species (phylum Blastocladiomycota), parasitic on the green alga Haematococcus," Mycological Research, Vol. 112, 2008, pp. 70-81.

[130] D. J. Fairbairn, A.S. Cavalloro, M. Bernard, J. Mahalinga-Iyer, M. W. Graham and J. R. Botella, "Host-Delivered RNAi: An Effective Strategy to Silence Genes in Plant Parasite Nematodes," Planta, Vol. 226, 2007, pp. 1525-1533.

[131] S. Sindhu, T R. Maier, M. G. Mitchum, R. S. Hussey, E. L. Davis and T. J. Baum "Effective and Specific in Planta RNAi in Cyst Nematodes: Expression Interference of Four Parasitism Genes Reduces Parasitic Success," Journal of Experimental Botany, Vol. 60, 2009, pp. 315-324.

[132] M. Karakas, "RNA Interference in Plant Parasitic Nematodes," African Journal of Biotechnology, Vol. 7, 2008, pp. 2530-2534. 